\title{
RESENHA
}

\section{EMPODERAMENTO, INTERSECCIONALIDADE E FEMINISMO NEGRO}

BERTH, Joice. O que é empoderamento? Belo Horizonte (MG): Letramento: Justificando, 2018.

\section{Priscila Moreira*}

O terceiro volume da coleção "Feminismos Plurais" organizado pela filósofa Djamila Ribeiro e recentemente publicado na França ${ }^{1}$ pela editora Anacaona é de autoria da arquiteta e pensadora feminista Joice Berth, que se dedica a responder à pergunta: O que é empoderamento?

Essa palavra, que no Brasil é considerada um neologismo de acordo com a autora, tem sido interpretada e utilizada para diferentes fins nas últimas décadas. Nesta obra, de 162 páginas e dividida em quatro capítulos, Berth se propõe a fazer um breve histórico do conceito e da palavra "empoderamento" trazendo sua importância para o Feminismo Negro por meio de uma relevante revisão bibliográfica de autoras como bell hooks, Lélia Gonzalez, Audre Lorde, Sueli Carneiro, entre outras.

No primeiro capítulo intitulado "O que é empoderamento?" a autora começa explicitando o conceito de poder à luz de importantes nomes da Filosofia, como Hannah Arendt e Michel Foucault. A partir disso e recorrendo ao pensamento feminista negro de Patricia Hill Collins a autora começa a estabelecer as bases para o que é mais central em sua obra: a importância do empoderamento na prática interseccional de luta coletiva contra as opressões históricas e sociais, principalmente no que diz respeito às opressões vividas por mulheres negras.

* Mestranda em Ciências da Religião pela Universidade Metodista de São Paulo. Psicóloga pela Universidade Federal Fluminense, especializada em Psicoterapia Existencial e Fenomenológica, graduanda em Teologia.

BERTH, Joice. Empowerment et feminisme noir. Paris :Editions Anacaona, 2019. 
A autora apresenta um breve histórico da palavra "empoderamento" que, originada do inglês "empowerment" (dar poder, capacitar), foi apropriada pela língua portuguesa e por vezes também foi esvaziada de sentido devido à forma acrítica e indiscriminada pela qual foi utilizada.

Berth, então, recorre ao pensamento de Paulo Freire e Barbara Bryant Solomon, entre outras autoras e autores, para traçar algumas interpretações possíveis e pertinentes à palavra "empoderamento", são elas: o empoderamento, à semelhança da Teoria da Conscientização Crítica de Paulo Freire, ocorre a partir da realidade concreta dos próprios indivíduos que, aliado aos estímulos externos, causa transformações nas suas realidades individuais e coletivas. O empoderamento, longe de ser um objetivo, é um processo que leva os indivíduos a conquistarem sua autonomia psicológica, econômica e política, estas, por sua vez, alcançadas por um processo coletivo de luta e empoderamento.

No segundo capítulo "Opressões estruturais e empoderamento: um ajuste necessário" a autora problematiza o uso do conceito por parte do neoliberalismo que o caracteriza como um projeto individualista e despolitizado, esvaziando seu sentido coletivo de luta e transformação das diversas opressões. A inserção da interseccionalidade no movimento feminista provoca um questionamento da categoria universal de "mulheres" trazendo maior abrangência à categoria ao mesmo tempo em que critica os pressupostos racistas na gênese do movimento feminista branco.

Esse fenômeno se dá pelo fato de que, algumas propostas políticas emancipatórias, não compreendem o empoderamento à luz das múltiplas opressões estruturais. Sendo assim, cometem o erro de dedicar-se a erradicar opressões pontuais e ignorar a situação estrutural de opressão que incidem de formas diferentes sobre grupos e indivíduos variados.

É nesse momento que Joice Berth inclui a discussão sobre interseccionalidade, tão fundamental para a resposta à pergunta que dá nome a essa obra. Apoiada nos estudos de Kimberlé Creenshaw e Sueli Carneiro, ela apresenta a situação das mulheres negras no Brasil e no mundo, deixando claro as intersecções de opressões vivenciadas por essas mulheres, bem como a necessidade de exercer um olhar cuidadoso ao traçar estratégias de empoderamento que as contemplem plenamente. 
Trazendo a noção de empoderamento para a discussão sobre políticas públicas, Berth recorre a pesquisadoras e pesquisadores nacionais a fim de esclarecer o papel do Estado no processo do empoderamento. De acordo com a autora, as políticas governamentais devem criar um ambiente favorável para o empoderamento dos indivíduos e dos coletivos, porém são esses mesmos grupos e indivíduos que protagonizam o processo de empoderar-se.

Em se tratando especificamente das mulheres negras, algumas políticas públicas de distribuição de renda se mostraram eficazes em certa medida para o processo de empoderamento. Porém ainda não suficiente, uma vez que são elas que vivenciam as privações a outros aspectos necessários para uma vida digna, a saber, educação de qualidade, acesso a moradias adequadas e condições psicológicas que the garantam bem-estar e saúde mental.

A participação democrática, de acordo com a autora, também é um importante fator a ser considerado no empoderamento de pessoas e coletivos que vivem em situações de desigualdades. A sociedade civil brasileira é marcada principalmente pela ausência de regulamentação que garanta a participação dos povos quilombolas, indígenas e negros nas consultas públicas. Sem participação democrática, não é possível falar em empoderamento.

No terceiro capítulo "Ressignificação pelo Feminismo Negro", Joice Berth aprofunda sua análise nas teorias feministas negras que norteiam seu entendimento sobre o empoderamento. É nesse ponto que a leitora e o leitor podem desfrutar, agora de forma mais detalhada, de pequenas provocações e apontamos feitos por pensadoras importantes como Angela Davis, bell hooks, Audre Lorde, Patricia Hill Collins e Sueli Carneiro. Estas autoras possibilitam um melhor entendimento da complexidade das múltiplas opressões e da interseccionalidade como método de análise e atuação política.

Partindo das análises destas autoras, Berth argumenta que o pensamento feminista negro evidenciou as formas como as opressões estão articuladas e como as mulheres negras já utilizavam estratégias de empoderamento mesmo antes desse conceito feminista ter sido cunhado. $\mathrm{O}$ empoderamento ressignificado pelas feministas negras exige 
uma postura interseccional ao lidar com as opressões estruturais. bell hooks, uma das autoras citadas neste capítulo, destaca a necessidade de uma ética do amor que possa motivar o desejo de mudança para além das lutas individuais contra aquilo que ofende e oprime grupos específicos, para chegar a uma ação comum que atinja a todas e todos no desejo por uma vida digna. De igual forma, Patricia Hill Collins afirma que é necessário compreender as tecnologias de articulação das opressões estruturais para que se criem estratégias de superação, ao nível da formação ou reconstrução das subjetividades, através da recuperação da autoestima, possibilidades de ascensão econômica, acesso à cultura e informação e formação de lideranças, por exemplo.

No maior e quarto capítulo "Estética e Afetividade: noções de Empoderamento", a autora introduz uma breve conceituação de estética como a área da Filosofia que se dedica a estudar o belo, compreendido como uma percepção manipulável e influenciável. A partir daí, Berth começa sua análise sobre os efeitos históricos da construção de uma supremacia estética de uma raça em detrimento de tantas outras.

A estética negra, exemplificada nos cabelos e nos traços faciais como nariz e boca, historicamente foram alvo de ridicularização por parte da mídia, fortemente influenciada pelos ideais racistas tendo em vista a persistente exploração dos negros, proporcionando acúmulo de privilégios sociais para os exploradores. Em contrapartida, e a fim de questionar os efeitos nocivos dessa suposta supremacia, os movimentos políticos em prol da emancipação do povo negro sempre apostaram no resgate da beleza negra como fundamentais para a autoestima e autodefinição de homens negros e mulheres negras.

Nas palavras da própria autora sobre o amor das mulheres negras aos seus próprios cabelos, "amá-lo significa cuspir de volta para a boca do sistema racista todas as ofensas, rejeições, exclusões que nos são direcionadas ao longo de toda uma vida" (p.95).

A valorização da estética negra afeta diretamente o amor das mulheres negras e homens negros por si mesmos. Esse amor, que foi estrategicamente sufocado e impedido pelo racismo e machismos estruturais, é um importante impulsionador de empoderamento individual e coletivo, pois desemboca naquilo que é crucial para o processo de 
empoderar-se: a admiração de si mesmo, de seu povo, de sua cultura e de sua ancestralidade.

Para as mulheres negras especificamente, Joice Berth considera que esse autoamor é de extrema importância, uma vez que, devido às construções sociais de dignidade humana, sempre associadas às mulheres brancas, as mulheres negras foram levadas, muitas vezes, a desacreditar no amor. Dessa forma, mais que uma estratégia de sobrevivência, a autoestima e o autoamor promovem libertações até as bases mais profundas da opressão racial e de gênero. Essa manifestação de afetividade realiza-se também a nível coletivo, provocando admiração e inspiração uns/umas n@s outr@s, estratégia importante na superação dos sistemas opressores.

Todos os aspectos trabalhados pela autora são, portanto, fundamentais para o processo de empoderamento. Este só se conclui plenamente em uma simbiose da ação individual e coletiva culminando na autonomia econômica, emocional e política dos grupos oprimidos em nossa sociedade.

Esta obra, assim como os outros volumes da coleção "Feminismos Plurais", destacando o já clássico "O que é lugar de fala?" de Djamila Ribeiro, caracteriza-se por sua acessibilidade na linguagem e no valor, tornando esse conteúdo possível de ser adquirido e compreendido por todas e todos. Fazendo uso de uma linguagem marcadamente feminista e negra, Joice Berth faz dessa obra uma leitura provocativa, esclarecedora e necessária sobre um termo que corre constantemente o risco de ser mal interpretado e utilizado levianamente de acordo com os interesses neoliberais. 